\title{
Managerial Cost Inefficiency and Takeovers of U.S. Thrifts
}

\author{
Fatma Cebenoyan \\ Hunter College-CUNY, U.S.A. \\ A. Sinan Cebenoyan \\ Hofstra University, U.S.A. \\ Elizabeth S. Cooperman \\ University of Colorado at Denver, U.S.A.
}

This paper uses a two-step methodology to examine the relationship between managerial cost inefficiency and the takeover of U.S. thrifts during a period of market liberalization and widespread takeover activity, 1994 to 2000. In the first stage using stochastic cost frontiers, controllable managerial cost inefficiency scores are estimated for all stock firms operating each year in 1994 to 2000. In a second stage, these scores are used to examine correlates of takeovers, focusing on cost inefficiency. For takeovers by banks, a significant negative relationship between cost inefficiency and takeover is found, suggesting an exit of more cost efficient firms from the thrift industry during this period. However, takeovers by thrifts are associated with other characteristics (JEL: G21, G33, G34).

Keywords: depository institutions, thrifts, takeovers and cost inefficiency.

\section{Introduction}

The landscape for global financial services has changed dramatically with the liberalization of regulatory environments in the recent past. Among other changes, this liberalization led to numerous mergers and takeovers across different types of financial institutions, and an overall

* We thank Anthony Saunders, and participants at the FMA 2002 meetings, and at Hofstra University Department of Finance Seminar Series for valuable comments. Fatma Cebenoyan acknowledges support from a CUNY Research Grant; Sinan Cebenoyan received support from a Summer Research Grant from the Frank G. Zarb School of Business at Hofstra University; and Elizabeth Cooperman thanks the University of Colorado-Denver for funds to help collect part of the data for this study.

(Multinational Finance Journal, 2005, vol. 9, no. 1 \& 2, pp. 23-42)

(C) Multinational Finance Society, a nonprofit corporation. All rights reserved. DOI: $10.17578 / 9-1 / 2-2$ 
wave of consolidations. This is particularly the case for the U.S. thrift industry, which experienced significant takeover activity during the later 1990 's. Legislation during this period encouraged merger activity, such as the removal of previous geographical restrictions for banks and thrifts under the Riegle-Neal Interstate Branching Act of 1994. Also, the removal of preferential tax treatment of bad debt reserves under a special provision of the Small Business Jobs Protection Act of 1996 eliminated previous impediments for thrift to bank conversions and mergers. Finally, the Gramm-Leach-Bliley Act (Financial Modernization Act) of 1999, by allowing the creation of Financial Holding Companies which could practice all functions 'financial in nature' under one umbrella, removed further obstacles to bank/thrift mergers.

Although the thrift industry has been very profitable in the last decade, there may be significant implications for the long-term viability of this sector if more or less efficient firms are being taken over. The characteristics of firms that have been taken over in a liberalized market are of interest to regulators, and managers as well, to determine if deregulation has promoted a healthier financial services industry. Thrift acquisitions may also provide insights as a relatively homogenous sub-sample of financial institutions, allowing researchers to generalize to a larger, more diverse population. In this paper the characteristics of U.S. thrifts that were taken over during this period of liberalization are examined focusing on the relationship between managerial cost inefficiency and takeovers.

Although characteristics of target thrifts have never been examined, a few studies have examined the relationship between takeovers of banks and firm characteristics. These include Hannan and Rhoades (1987), Moore (1996), Hadlock, Houston, and Ryngaert (1999), and Wheelock and Wilson (2000).

These studies focus on whether mergers serve to filter out unfit firms from the banking industry, as in what Hannan and Rhoades (1987) refer to as a "driving out bad management" hypothesis. This hypothesis predicts that poorly managed firms will be culled out of the industry, as acquirers seek to gain from turning these firms around. Similarly, Moore (1996) notes that mergers may remove banks that are "out of step" in a rapidly changing environment, allowing more productive use of resources and enhancing the industry's profitability. Hadlock, Houston, and Ryngaert (1999) point out, bank managers have greater control over whether or not they are acquired, since few hostile takeovers are allowed by regulators. From this perspective, they examine the 
relationship between takeovers and performance and ownership characteristics as well.

Hannan and Rhoades (1987) studying a sample of Texas banks from 1971 to 1982, find no support for a removal of bad management hypothesis, with insignificant relationships between takeovers and firm profitability. Similarly, Hadlock, Houston, and Ryngaert (1999), examining paired samples of large acquired and not acquired banks from 1982 to 1992, find insignificant relationships between takeovers and profitability and managerial ownership factors. Moore (1996), however, studying a large sample of banks from 1993 to June 1996, finds a higher probability of takeover for firms with lower profitability. His results support the "driving out bad management hypothesis" as both lower profitability and lower market success (as proxied by a lower market share) lead to higher probability of takeovers.

Since managers may have greater control over cost efficiency versus profitability factors in the banking industry, an examination of cost efficiency may be a better test of a bad management hypothesis. Wheelock and Wilson (2000) is the only previous study that examines this relationship for the banking industry. Unlike studies that use logit models, Wheelock and Wilson (2000) use a proportional hazard model to find predictive determinants of a bank's survival time to both failure and takeover. They follow a large sample of banks with at least $\$ 50$ million in assets in existence in 1984 through 1993. Their model includes proxies for managerial cost inefficiency, and other firm-specific and market variables. They find different determinants for bank failures versus acquisitions. While inefficiency increases the probability that a bank will fail, it reduces the probability that a bank will be acquired. Wheelock and Wilson (2000, p.134) note that although inefficient banks might be "ripe for takeover" for their turnaround potential, "the costs of reorganizing an inefficient bank and the potential for hidden problems that inefficiency might signal tend to discourage the acquisition of inefficient banks." Their results contrast with previous studies examining bank mergers in the 1980's that find little evidence of post-merger cost efficiency gains for banks (see Calomiris and Karceski, [2000]). Their results also contrast with findings by Trimbath, Frydman, and Frydman (2001), using the same methodology, of a significant positive relationship between cost inefficiency and takeovers of non-financial, Fortune 500 firms during 1980 to 1997 . Their differing results may reflect average acquirer motivations across diverse industries versus a single, more regulated banking industry. 
As the only study examining managerial cost inefficiency and takeovers for the banking industry, Wheelock and Wilson's (2000) results have not been confirmed for the liberalized takeover market of the later 1990's, which encompassed different conditions and a less restricted regulatory regime. Similarly, by examining banks that often are involved in very diverse activities, their aggregate results may smooth over differences among banks, specializing in different types of lending.

This paper contributes to the previous literature on the characteristics that affect a financial services firm's acquisition by: (1) being first to examine the relationship between managerial cost inefficiency and other factors affecting takeovers for the thrift industry; (2) choosing its sample period for years that had the least amount of regulatory restrictions, with the liberalization of depository institution markets in the later 1990's; and (3) focusing on relatively homogenous firms in the thrift industry, avoiding heterogeneity that is often found in the banking industry that could distort aggregate results.

The relationship between cost inefficiency and thrift takeovers is examined using a two-stage procedure. In the first stage, inefficiency scores for individual thrifts for each year are estimated using a stochastic cost-frontier methodology. In the second stage, maximum likelihood logit models are estimated using the 2,533 lagged, firm-year inefficiency scores that were calculated, along with other firm-specific and market characteristics. Though the focus is the target rather than the acquirer, nevertheless a multinomial logit analysis is conducted as a final test to detect differences in takeover attributes based on the identity of the acquirer, whether it is a bank or another thrift. Based on the general logit model for all takeovers, results consistent with Wheelock and Wilson (2000) of a significant, negative relationship between cost inefficiency and takeovers are found. Interestingly, multinomial logit results indicate quite different attributes for takeovers depending on who the acquirer is. Takeovers by commercial banks are associated with higher cost efficiency and a more rapidly growing market. However, takeovers by another thrift are correlated with larger size overall, but lower thrift-market share.

The paper proceeds as follows. Section II presents the data and the methodology. Section III presents the empirical results, followed by a summary and conclusions in section IV. 


\section{Data and Methodology}

Data on thrifts are collected from the Office of Thrift Supervision Consolidated Statements of Condition and Operations, as recorded by Thomson Financial for all U.S. stock-chartered thrifts operating in 1994-2000. Inefficiency scores are estimated annually using data of all stock thrifts in every year during the testing period of seven years. At this stage, the number of thrifts range from 865 in 1994 to 650 in 2000. A minimal number of firm-years (21 in all) are lost during this estimation period due to missing information.

To examine characteristics of takeovers, previous studies have used either: (1) a logit model to examine ex-post characteristics that are correlates of takeovers; or (2) a proportional hazard model to predict the time to hazard (takeover). Logit models are simpler and require fewer restrictive assumptions, such as constant proportionality. However, they can be biased as predictive models for the temporal risk of takeover (see Trimbath, Frydman, and Frydman, [2001]). Since the purpose of this study is to examine ex-post correlates of takeovers versus prediction, the simpler logit approach is used. Trimbath, et al. (2001) note a potential bias for logit models that use beginning of the period characteristics of firms that are not taken over until much later. This paper avoids this bias by using the methodology used by DeFond and Park (1999), where all existing thrifts in 1994 are followed through 2000 and non-target thrifts are included every year, but targets are included only in the year of their takeover. These procedures yield 2,533 firm-year observations, including 401 takeovers.

To identify takeovers, the Thomson Savings Directory for 1994 to 2001 (Skokie, Illinois: Thomson Financial Publishing Company), and for acquisition year verifications the National Information Center, Federal Reserve System website are used. Other data sources used for other independent control variables included are: (1) U.S. Department of Commerce Bureau of the Census County and City Data Book; and (2) County and City Extra: Annual Metro, City, and County Data Book (Lanham, Maryland: Bernan Press, ed. by Courtenay M. Slater and George E. Hall), and (3) the Bureau of Economic Analysis: Regional Accounts Data, Annual State Personal Income, and Annual Population by State on the BEA website (www.bea.gov/bea/regional/spi/).

\section{A. Cost Inefficiency Measures}

In this paper the economic efficiency concept employed is cost 
inefficiency. Cost inefficiency gives a measure of how much a particular firm's cost deviates from the best practice firm's minimum cost for the same output under the same conditions. This information is derived from a cost function that evaluates the firm's variable costs in terms of variable outputs, variable input prices, fixed inputs, random error and inefficiency. It can be stated as:

$$
C=f(y, w, z, u, v)
$$

where $C$ equals variable costs, $y$, vector of variable outputs, $w$, a vector of prices of variable inputs, and $z$ are quantities of any fixed inputs included to account for their effects on variable costs, since they may be substitutable or complementary with variable inputs. The terms $u$ and $v$ are, respectively, inefficiency and random error terms. To estimate each firm's cost inefficiency index $u$, the following well-known multiproduct trans-log cost specification (suppressing individual thrift subscripts) is used: ${ }^{1}$

$$
\begin{gathered}
\ln C=\alpha+\sum_{j=1}^{5} \beta_{j} \ln y_{j}+\sum_{k=1}^{2} \gamma_{k} \ln w_{k}+\frac{1}{2} \sum_{j=1}^{5} \sum_{i=1}^{5} \beta_{j, i} \ln y_{j} \ln y_{i} \\
+\frac{1}{2} \sum_{k=1}^{2} \sum_{i=1}^{2} \gamma_{k, i} \ln w_{k} \ln w_{i}+\sum_{j=1}^{5} \sum_{k=1}^{2} \delta_{j, k} \ln y_{j} \ln w_{k} \\
+\sum_{k=1}^{2} \ln z_{k}+\ln u+\ln v
\end{gathered}
$$

As pointed out by previous studies, the trans-log function provides consistent inefficiency rankings relative to other functional forms. It also has the advantage of simplicity. ${ }^{2}$

In this estimation, five outputs, $y$, are used: (1) 1-4 family mortgage loans and mortgage-backed securities; (2) multifamily and

1. See Aigner, Lovell and Schmidt (1977), Meeusen and Broeck (1977), Jondrow et al (1982) for a description of this methodology. For more recent applications, see Cebenoyan, et al. (1993), Berger and Mester (1997) and Rogers (1998).

2. For greater precision in calculating efficiency scores, Berger and Mester (1997) suggest the use of a Fourier-flexible function form, which is less restrictive than a translog cost function. However, the trans-log form is easier to use, and for ranking decisions, studies demonstrate that it provides similar rankings as other forms. 
nonresidential mortgage loans; (3) non-mortgage loans including consumer and commercial loans and lease financing; (4) cash and other security investments including U.S. government and agency securities, municipals, and other securities; and (5) construction and land loans, and real estate and service-corporation investments. The prices of two variable inputs, $w$, are used: (1) labor and (2) deposits and other borrowings. The price of labor is measured as total expenditures on employees divided by the number of full-time equivalent employees at the end of the year. The price of deposits is total interest expense divided by total deposits and other borrowings. The usual linear homogeneity in input price restrictions are imposed in estimation. Two fixed input quantities, $z$, are also included: the dollar value of physical capital (premises and other fixed assets) and the dollar value of financial equity capital. ${ }^{3}$

\section{B. Logit Model}

In the second stage of the estimation, maximum likelihood logit models are used to examine the relationship between acquisitions and cost inefficiency and other factors. The logit model permits an analysis of the binary dependent variable of a thrift being taken over versus continuing to operate independently. The MLE logit model is based on the cumulative logistic probability function and is specified as: ${ }^{4}$

$$
P_{i}=F\left(\alpha+\beta X_{i}\right)=\frac{1}{1+\exp \left(-Z_{i}\right)}
$$

where $Z_{i}$ is an unobservable index related directly to the probability of takeover, and specified as:

$$
Z_{i}=\alpha+\beta_{1}{C I N E F F_{i}}+\beta_{2} \operatorname{SIZE}_{i}+\beta_{3} \mathrm{CAP}_{i}+\beta_{4} \mathrm{MSH}_{i}
$$

3. See Rogers (1998) and Berger and Mester (1997) for a detailed description of the methodology, which this section heavily draws from. The input and output measures are similar to those used by Cebenoyan, et al. (1993) and Cebenoyan, Cooperman, and Register (1993). We use a financial intermediation approach, following the arguments of Sealey and Lindley (1977) to specify thrift inputs and outputs. Results of the frontier estimations are available from the authors upon request.

4. See Pindyck and Rubinfeld (1981) and Judge, et al. (1982) for reviews of maximum likelihood logit models. 


$$
\begin{gathered}
+\beta_{5} \text { TRAD }_{i}+\beta_{6} \text { REPOS }_{i}+\beta_{7} \text { PROF }_{i}+\beta_{8} \text { MSA }_{i} \\
+\beta_{9} \text { GROWTH }_{i}+\sum_{j=10}^{16} \beta_{j} \text { YEAR }_{j}+\varepsilon_{i},
\end{gathered}
$$

where $P_{i}=1$ if a thrift is taken over during the merger wave of 1995 to 2001 and 0 , otherwise, $C I N E F F_{i}$ is a cost inefficiency score, $S I Z E_{i}$ is the $\log$ of total assets, $C A P_{i}$ is the ratio of total equity to total assets, $M S H_{i}$ is market share of state thrift assets, $T R A D_{i}$ is the percentage of traditional home-mortgage assets, $R_{E P O S_{i}}$ is the percentage of repossessed assets, $P R O F_{i}$ are profitability ratios (ROA or ROE), $M S A_{i}$ is a dummy variable indicating operation in a Metropolitan Statistical Area, $G R O W T H_{i}$ is the population growth percentage of the state in which the thrift operates, $Y E A R_{j}$ are year dummies, and $\varepsilon_{i}$ is a random error term.

As in previous studies (Hannan and Rhoades [1987]), explanatory variables are lagged one year to allow a reasonable time lag between a thrift's firm-specific and environmental conditions and its takeover activity.

To test a bad (or inefficient) management hypothesis, the relationship between cost inefficiency (CINEFF) and the likelihood of a thrift's takeover (Hannan and Rhoades [1987] and Moore [1996]) is examined. Under the bad management hypothesis, the coefficient of CINEFF is expected to be significant and positive, with more inefficient thrifts associated with takeovers. An alternative explanation is that inefficiency can be an unattractive attribute signaling problems with the target (Wheelock and Wilson [2000]). Due to the potential costs of bringing the firm around, acquiring firms may have stayed away from inefficient targets decreasing the likelihood of takeover for inefficient thrifts. Under this alternative, the coefficient on CINEFF is expected to be significantly negative instead.

Several firm-specific attributes are included to control for other factors expected to affect takeover probability. SIZE is measured as the $\log$ of thrift's total assets and is incorporated in the analysis to account for size related takeover incentives such as building market power. ${ }^{5}$ Capital adequacy, CAP, a firm's equity to assets ratio, is one of the

5. The results are robust to other size selections such as total assets and total equity. We have also removed linearity and log-linearity in this variable by creating 5 size-class dummies. Our results did not change. 
variables often cited as a possible factor in affecting acquisition activity (Wheelock and Wilson [2000], Hannan and Rhoades [1987] and Moore [1996]). Capitalization can affect the takeover activity in either direction: On the one hand, high capital ratios of targets may be a desirable attribute to provide additional capital for an acquirer. On the other hand, firms with high capital ratios may demand higher prices which may push acquiring firms towards less costly, inadequately capitalized firms that they could turn around by providing greater capital. CAP also signals potential problems as it indicates the amount of safety buffer a firm has against insolvency risk.

Market share, $\mathrm{MSH}$, is another variable that has received attention in the literature as a potential factor in takeover activity, with mixed implications. Hannan and Rhoades (1987) argue that market share is a good attribute in a target since it provides "good market position" and "visibility," and is expected to have a positive relationship with takeover probability. Moore (1996), however, points out that a firm's high market share can have a negative effect on the regulatory approval prospects of a takeover; hence a negative significant relationship would be expected. Yet, he also argues that a firm's low market share, indicating "lack of success in its marketplace," may be a desirable attribute as a more successful acquirer may seek that firm for its turnaround potential. A thrift's market share in this study is measured in terms of its assets as a percentage of total assets of all thrifts in the state in which it operates. ${ }^{6}$ To control for asset portfolio differences that may have affected the likelihood of takeover, TRAD, the percentage of home mortgage assets held by a thrift, is included. The effect of TRAD on takeover probability is not immediately clear. For instance, acquirers may prefer thrifts with high levels of TRAD to diversify their asset base, thus implying a positive relationship between takeover and TRAD. Alternatively, in an industry where asset portfolio variation is limited, higher levels of TRAD may signal a lack of creativity on the part of management, and/or a lack of market breadth and depth with low potential for creativity in product offerings, thus a negative relationship. To control for differences in risk that might be associated with takeovers, REPOS, the ratio of repossessed assets to total assets is included. REPOS proxies for the quality of a thrift's loan portfolio. With

6. Radecki (1998) argues that state, rather than city or county, provides better boundaries for retail banking markets. Geographic restrictions on within state branching were removed across the U.S. in almost all states by the end of 1992 . 
TABLE 1. Descriptive Statistics for Thrifts Acquired and Not Acquired During 1995-2001

\begin{tabular}{|c|c|c|c|c|c|}
\hline Variables & Sample & $N$ & Mean & $\sigma$ & $\mathrm{t}-$ stat \\
\hline Size & All & 2533 & 12.273 & 1.47 & \\
\hline \multirow[t]{2}{*}{$(\log )$} & Acquired & 401 & 12.343 & 1.474 & \\
\hline & Not Acquired & 2132 & 12.259 & 1.469 & -1.05 \\
\hline Capital & All & 2533 & 0.09 & 0.047 & \\
\hline \multirow[t]{2}{*}{ Ratio } & Acquired & 401 & 0.093 & 0.042 & \\
\hline & Not Acquired & 2132 & 0.089 & 0.048 & -1.51 \\
\hline Market & All & 2533 & 0.057 & 0.128 & \\
\hline \multirow[t]{2}{*}{ Share } & Acquired & 401 & 0.055 & 0.119 & \\
\hline & Not Acquired & 2132 & 0.058 & 0.13 & 0.479 \\
\hline MSA & All & 2533 & 0.694 & 0.46 & \\
\hline \multirow[t]{2}{*}{ Dummy } & Acquired & 401 & 0.77 & 0.42 & \\
\hline & Not Acquired & 2132 & 0.68 & 0.466 & $-3.60 * * *$ \\
\hline Population & All & 2533 & 1.624 & 1.685 & \\
\hline \multirow[t]{2}{*}{ Growth } & Acquired & 401 & 2.037 & 2.097 & \\
\hline & Not Acquired & 2132 & 1.546 & 1.584 & $-5.38 * * *$ \\
\hline Cost & All & 2533 & 0.234 & 0.177 & \\
\hline \multirow[t]{2}{*}{ Inefficiency } & Acquired & 401 & 0.193 & 0.153 & \\
\hline & Not Acquired & 2132 & 0.242 & 0.181 & $5.10 * * *$ \\
\hline Traditional & All & 2533 & 0.463 & 0.184 & \\
\hline \multirow[t]{2}{*}{ Loan $\%$} & Acquired & 401 & 0.451 & 0.173 & \\
\hline & Not Acquired & 2132 & 0.465 & 0.186 & 1.32 \\
\hline Repossessed & All & 2533 & 0.004 & 0.01 & \\
\hline \multirow[t]{2}{*}{ Assets \% } & Acquired & 401 & 0.003 & 0.006 & \\
\hline & Not Acquired & 2132 & 0.004 & 0.01 & $2.08 * *$ \\
\hline Profitability & All & 2533 & 0.007 & 0.013 & \\
\hline Ratio-Returns & Acquired & 401 & 0.005 & 0.013 & \\
\hline on Assets & Not Acquired & 2132 & 0.008 & 0.013 & $4.28 * * *$ \\
\hline
\end{tabular}

Note: The t-statistics refer to t-tests comparing the means of the two samples. ***, ** $p<0.01$ and $p<0.05$, respectively. Variable definitions: Size (SIZE) $=$ Log of Total Assets (in thousands). Capital Ratio $(\mathrm{CAP})=$ Equity to Total Assets. Market Share $(\mathrm{MSH})=$ Thrift's Assets to Total State Thrift Assets. MSA dummy (MSA) $=1$ if in an MSA, 0 otherwise. Population Growth $($ GROWTH $)=$ Annual Growth in Population in a Firm's Home State. Cost Inefficiency $($ CINEFF $)=$ Thrift's Controllable Managerial Inefficiency Score. Traditional Loan \% (TRAD) = Thrift's Percentage of Traditional Home-Mortgage Assets Repossessed Assets \% (REPOS) = Thrift's Percentage of Repossessed Assets. Return-onassets \% $(\mathrm{PROF})=$ Thrift's profitability as measured by its return on assets. 


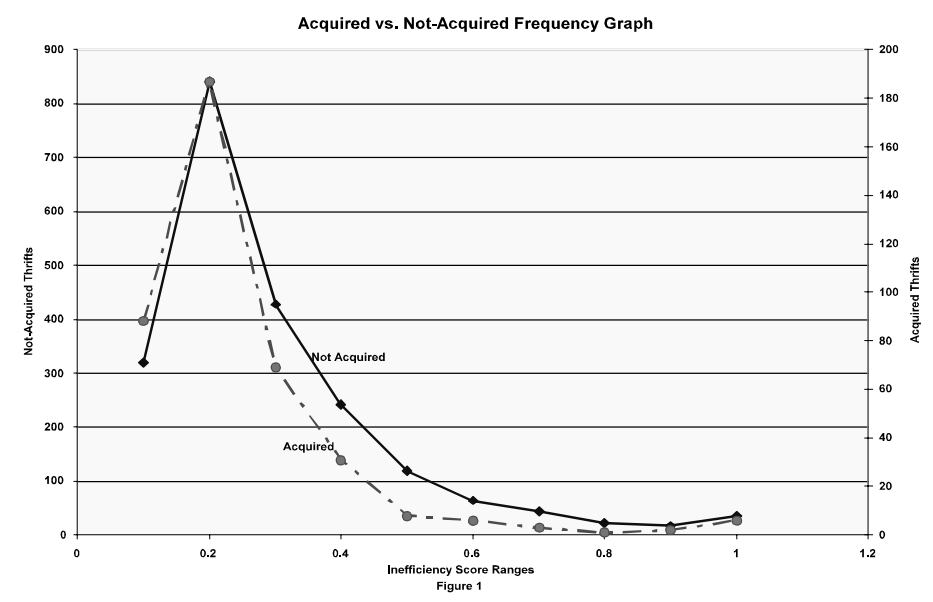

FIGURE 1.- Acquired vs. Not-Acquired Frequency Graph

bad debt reserve recaptures required after 1996 for thrifts, a firm with larger REPOS might make a less attractive target. PROF, a thrift's profitability as measured by its return-on-assets (and return-on-equity as an alternative specification), is also included since firm profitability is consistently discussed in the literature as a possible determining factor in merger activities (Hannan and Rhoades [1987], Moore [1996], Wheelock and Wilson [2000]). The expectation in these studies is that lower profitability adversely affects takeover probability.

Two additional variables are included to control for the economic environment in which the firms operate. An MSA dummy is employed to distinguish different types of markets the targets are located in. Moore (1996), for example, finds a greater probability of takeover for banks operating in non-rural markets that offer greater opportunity for growth. A positive coefficient on this variable would provide evidence for the hypothesis that firms may target thrifts operating in more urban markets in the state. Population growth percentage, GROWTH, is also included to account for expansion opportunities in the target market. All else equal, growth prospects of the market may encourage the acquirers to target thrifts in such areas, see Hannan and Rhoades (1987).

Finally six time dummy variables for 1994 through 1999 are included, with the last year of 2000 omitted, to account for the year-effects. 


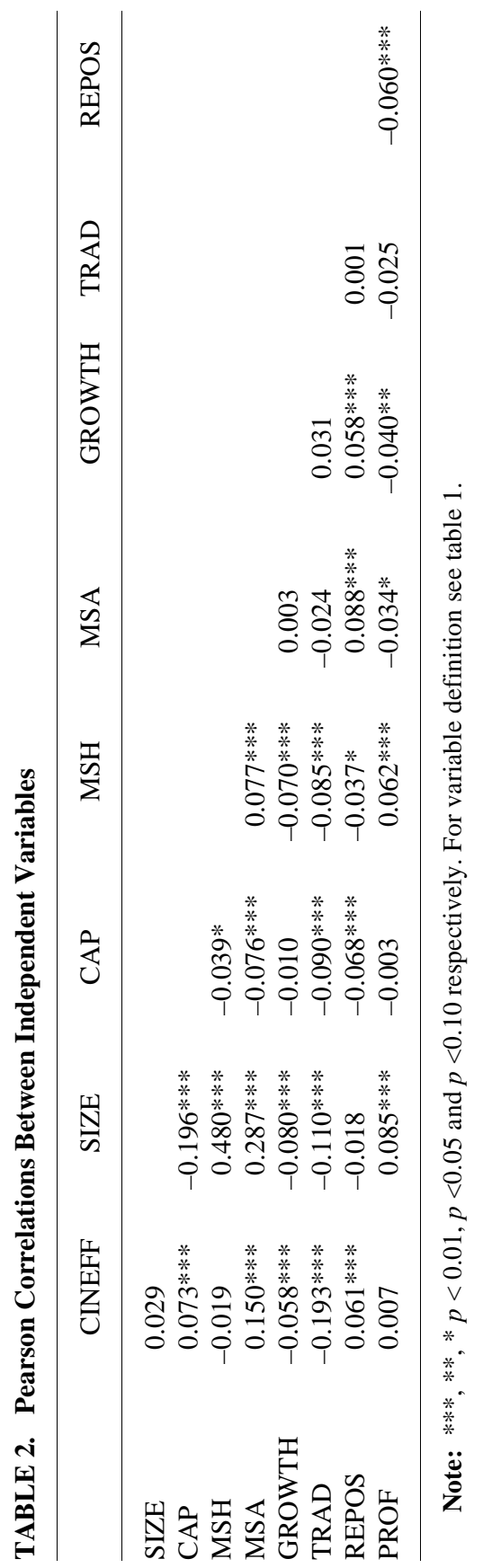


to target thrifts in such areas, see Hannan and Rhoades (1987).

Finally six time dummy variables for 1994 through 1999 are included, with the last year of 2000 omitted, to account for the year-effects.

\section{Empirical Results}

\section{A. Descriptive Statistics}

Descriptive statistics for both groups of acquired and not-acquired firms are shown in table $1 .^{7}$ The differences in means test show that more acquired firms were located in urban markets (MSA dummy) with higher population growth (GROWTH) than non-acquired firms, supporting the hypothesis that significant markets with growth opportunities potentially raise the probability of takeover. Acquired firms seem to have less risky assets as measured by repossessed loans (REPOS) indicating that thrifts with risky assets are less desirable targets. Acquired firms seem to be more cost efficient than not-acquired firms, providing at least descriptive evidence contrary to the bad management hypothesis. ${ }^{8}$ As shown on figure 1 , the distributions of CINEFF scores of acquired and not-acquired firms are very similar suggesting that the results are not driven by their distributional characteristics. Finally, acquired firms tend to have a lower rate of return on assets compared to not-acquired firms. Table 2 presents Pearson correlations between independent variables included in the logit analysis. The measures of market share and size are correlated with a Pearson correlation coefficient of 0.48 which signals a possible need of these variables to be evaluated individually in the logit analysis. Although most of the remaining variables seem to be correlated at significant levels, the magnitude of these correlations do not indicate potential multicollinearity problems $(|<0.30|)$.

7. The median test on the equality of medians is also performed for these variables (except dummy variables) with very similar results.

8. Inefficiency scores estimated using Equation (2) represent individual firm deviations from the best-practice frontier due to factors within managers' control, and range between 0 and 1 . As reported on Table 1, our CINEFF mean is 0.234 suggesting that an average thrift's costs are 23.4 percent greater than they would have been if the thrift had operated at its best-practice level. 


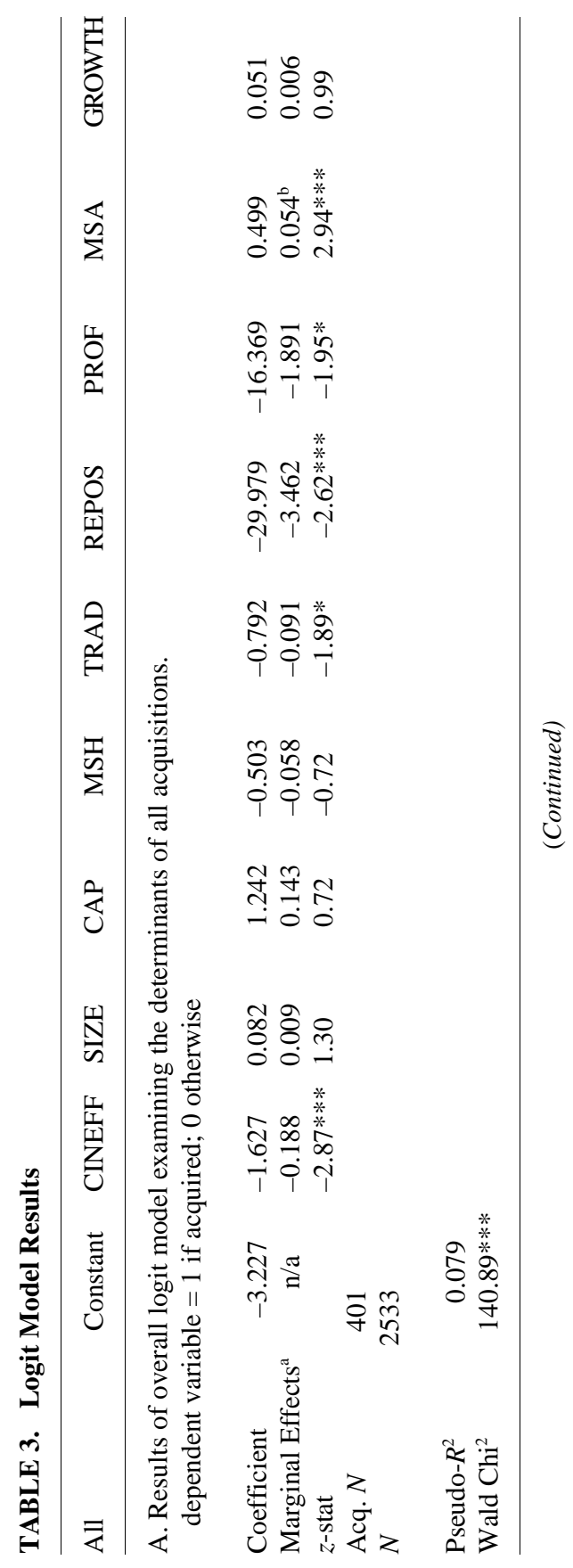




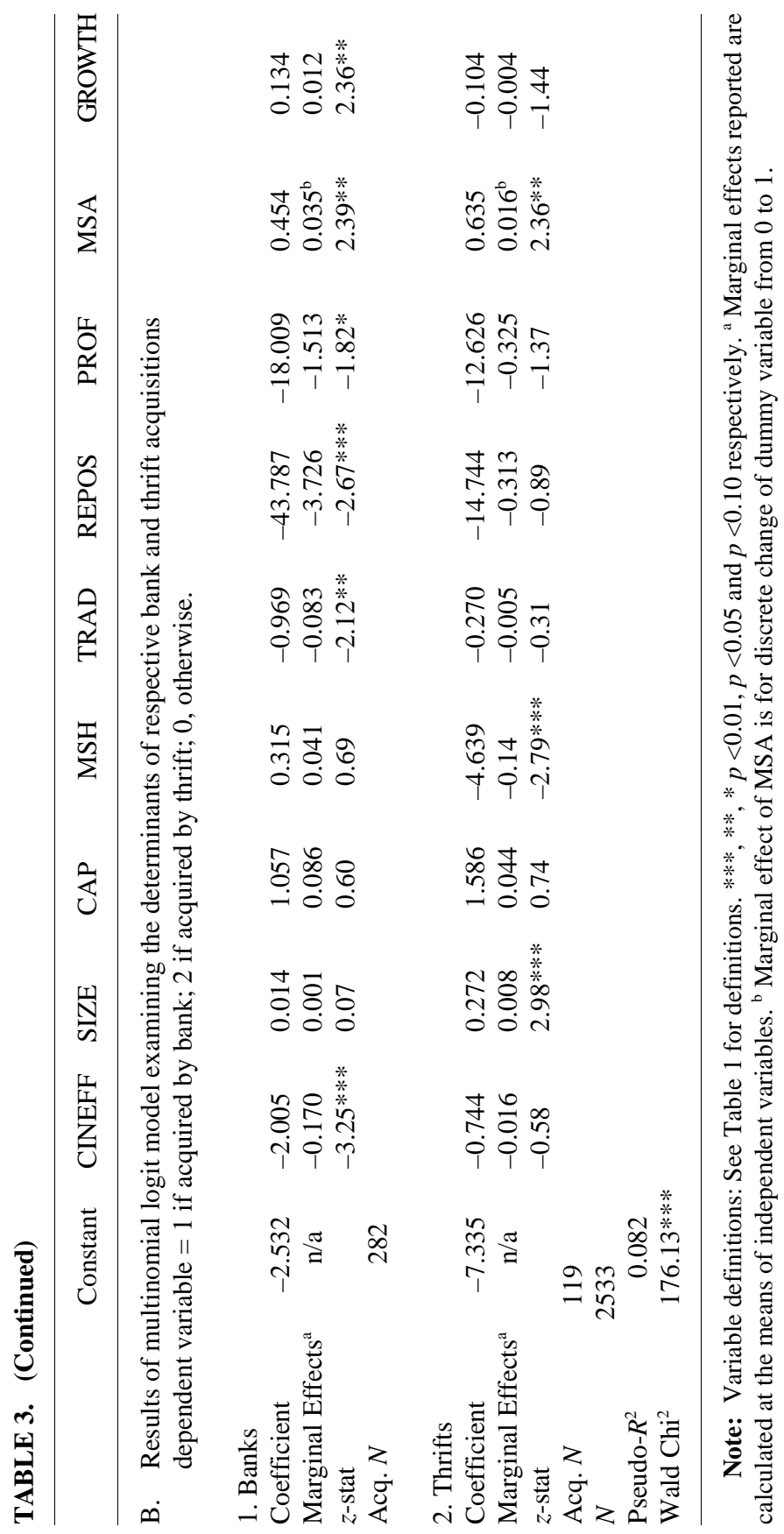




\section{B. Logit Model Results}

The results for the maximum likelihood logit regressions for the total sample are shown in panel A of table 3. ${ }^{9}$ The coefficient on CINEFF is negative and highly significant. Cost inefficiency appears to have been an undesirable attribute in a firm, consistent with Wheelock and Wilson's (2000) results. Cost inefficient firms are negatively associated with takeovers during this period. ${ }^{10}$ As predicted, thrifts with a higher risk profile, as measured by REPOS, are less likely to be taken over. TRAD, measuring thrift's percentage of traditional loans, also has a significant, negative coefficient implying that firms with a greater fraction of traditional loans were less attractive as takeover targets. This may indicate low desirability of concentrated portfolios, and reflecting perhaps the lack of greater adaptation to changing financial service markets. High TRAD firms may potentially be less adaptive to change and this may be an undesirable quality in a world where diverse financial functions are being collected under one umbrella. TRAD may also be an indicator of limited investment opportunities in the environment of the thrift in question. It may indicate that there is limited potential to expand into newer products. Consistent with Wheelock and Wilson (2000) and Moore (1996), but unlike Hannan and Rhoades (1987) who found no significant relation between profitability and acquisitions, the coefficient on PROF is negatively significant. This supports arguments that firms with low profitability might be acquisition targets due to their potential for greater profits under new owners; see Moore (1996). ${ }^{11}$ The coefficient on the MSA dummy variable is positive and highly significant as evidenced in the previous studies, supporting the argument that the firms within urban markets are

9. Due to inclusion of repeated observations on individual firms in the data set, we obtained and reported results using robust (Huber/White) variance estimates which produce "correct" standard errors even if the observations are correlated.

10. To address the possible bias introduced by potential errors in variables problem, an instrumental variable with a value of 1 for observations with inefficiency scores $>$ median (CINEFF) and -1 for observations with scores <median (CINEFF) is used to replace the variable CINEFF in equation (4) above (Greene, 1993, pg. 284, and Maddala, 1977, pg. 296). The results from the logit regressions with this instrumental variable in place of CINEFF remained unchanged, in terms of both direction and significance, from the ones reported here.

11. The model is re-estimated using ROE, return-on-equity, as an alternative specification of firm profitability with similar results. 
more desirable targets than smaller rural markets. This also indirectly supports the contention expressed earlier that in a changing environment potential growth in a variety of products is considered desirable.

The coefficients on the other environmental variable of population growth, GROWTH, and other firm-specific characteristics of size, capital ratio and market share (SIZE, CAP, and MSH) are insignificant at conventional levels. The signs on these coefficients, although insignificant, suggest that larger thrifts, thrifts in high population growth areas, and better capitalized thrifts have been considered to be more attractive for acquisition. Due to the high correlation reported on table 2 between market share and size, the analysis is repeated using these variables individually in estimating equation (4) with no change in results (not reported). ${ }^{12}$

A further investigation is carried out to see if there were different incentives for takeover activity for different types of acquirers. Out of the 401 thrift takeover sample, 282 represent thrifts taken over by banks, and 119 taken over by other thrifts. Since banks and thrifts may represent different markets of retail banking system with different business models, the multinomial logit estimation of equation (4) is estimated to investigate whether their acquisition incentives differed as well. This model includes as a dependent variable three outcomes of no takeover, takeover by a bank, and takeover by a thrift. The results are reported in panel B of table 3. If the acquirer is a bank, the explanatory variables CINEFF, MSA, TRAD, REPOS, and PROF show the same direction and significance as discussed above for the overall logit model shown in panel A. Additionally, for banks, population growth has a significant, positive relationship to takeover. Takeovers by banks tend to occur if a thrift operates in a more attractive, potentially higher growth market, as indicated by the positive, significant coefficient on GROWTH.

If the acquirer is another thrift, though, results change. With the exception of MSA, which holds its direction and significance the same, the other variables that show significant effects lose their significance at conventional levels. For example, inefficiency and repossessed assets are still undesirable, but insignificant attributes. SIZE, on the other hand, seems to have been an important factor in thrifts' target choices.

12. The effects of year dummies are not reported in tables since they are not of direct interest. But casual inspection shows that year dummies map out the relationship between the years and the volume of takeover activities within those years, with highest significant coefficients on years with the greatest number of takeovers in our testing period. 
Interestingly, though, thrift acquirers choose firms with low state thrift asset market shares. Consistent with Moore (1996), the coefficient on MSH is found to be significantly negative when the acquirer is a thrift. Moore (1996) notes that such a negative relationship reflects a lack of market success as a desirable characteristic to acquirers, perhaps for the thrift's turnaround potential by a successful acquirer. Although this study does not examine acquirer motives, which remains for future research, the differences in characteristics of taken over versus non-taken over thrifts suggest different motives for thrift versus commercial bank acquirers during this period. Banks appear to have preferred to acquire thrifts with efficient management. They also showed preferences for thrifts that operated in attractive, higher growth, urban markets, and thrifts that had already adapted to new market conditions by engaging in non-traditional lending. Thrift acquirers, however, showed preferences for larger thrifts that had less market success in terms of a lower state market share, perhaps for their turnaround potential or possibly to avoid anti-competitive factors that may reduce the chance of a successful merger, as Moore (1996) suggests.

\section{Summary and Conclusions}

This paper is the first to examine takeovers for the U.S. thrift industry during a period of market liberalization and widespread takeover activity, 1995 to 2001. The focus is on the relationship between cost efficiency and takeovers. First, yearly cost inefficiency scores are estimated using a stochastic cost frontier methodology for all firms from 1994 to 2000. In the second stage, the relationship between (lagged) managerial cost inefficiency and the likelihood of a firm's takeover, among other factors, is examined. Contrary to a "bad management hypothesis," that predicts inefficient firms will be culled from the industry, targets appear to be more cost efficient firms. However, examining differences in the characteristics of firms taken over by banks versus by other thrifts, this relationship only holds for bank acquirers. Bank acquirers also appear to target thrifts in high growth, urban markets, and thrifts that adapted to change in terms of engaging in greater non-traditional lending. For thrift acquirers, targets appear to be larger with lower thrift market asset shares, which as suggested by Moore (1996), may indicate a lack of market success. The results for 
bank takeovers are consistent with those of Wheelock and Wilson (2000) examining an earlier period and using a different methodology. The result that more efficient thrifts are taken over by banks bodes well for the health of the banking industry, but suggests for the thrift industry a removal of its more efficient firms.

\section{References}

Aigner, D. J.; Lovell, C. A. and Schmidt, P. 1977. Formulation and estimation of stochastic frontier production function models. Journal of Econometrics 6: 21-37.

Berger, A. N. and Mester, L. J. 1997. Inside the black box: What explains differences in the efficiencies of financial institutions? Journal of Banking and Finance 21: 895-947.

Calomiris, C. W. and Karceski, J. 2000. Is the bank merger wave of the 1990s efficient? In S. N. Kaplan (ed) Mergers and Productivity. Chicago and London: University of Chicago Press.

Cebenoyan, A. S.; Cooperman, E. S. ; Register, C. A. and Hudgins, S. C. 1993. The relative efficiency of stock versus mutual S\&Ls: A stochastic cost frontier approach. Journal of Financial Services Research 7: 151-170.

Cebenoyan, A. S.; Cooperman, E. S. and Register, C. A. 1993. Firm efficiency and the regulatory closure of S\&Ls: An empirical investigation. Review of Economics and Statistics August: 540-545.

DeFond, M. L. and Park, C. W. 1999. The effect of competition on CEO turnover. Journal of Accounting and Economics 27: 35-56.

Greene, W. H. 1993. Econometric Analysis, Second Edition: Macmillan Publishing Company.

Hadlock, C.; Houston, J. and Ryngaert, M. 1999. The role of managerial incentives in bank acquisitions. Journal of Banking and Finance 3: 221-249.

Hannan, T. H. and Rhoades, S. A. 1987. Acquisition targets and motives: The case of the banking industry. Review of Economics and Statistics 69: 67-74.

Jondrow, J. C.; Lovell, A. K.; Materov, I. S. and Schmidt, P. 1982. On estimation of technical inefficiency in the stochastic frontier production function model. Journal of Econometrics 46: 229-245.

Judge, G. G.; Hill, R. C.; Griffiths, W. E.; Lutkepohl, H. and Lee, T. 1982. Introduction to The Theory \& Practice of Econometrics: New York: John Wiley and Sons.

Maddala, G. S. 1977. Econometrics. McGraw Hill Book Company.

Meeusen, W. and Broeck, J. 1977. Efficiency estimation from Cobb-Douglas production function with composed error. International Economic Review 18: 435-444. 
Moore, R. R. 1996. Banking's merger fervor: Survival of the fittest? Financial Industry Studies, Federal Reserve Bank of Dallas (December): 9-15.

Pindyck, R. S. and Rubinfeld, D. L. 1981. Econometric Models and Economic Forecasts. New York: McGraw-Hill Book Company.

Radecki, L.J. 1998. The expanding geographic reach of retail banking markets. Economic Policy Review, Federal Reserve Bank of New York: 15-34.

Rogers, K. E. 1998. Nontraditional activities and the efficiency of U.S. commercial banks. Journal of Banking and Finance 22: 467-482.

Sealey, C. W., Jr. and Lindley, J. T. 1977. Inputs, outputs, and the theory of production and cost at depository financial institutions. Journal of Finance 32: 1251-1266.

Trimbath, S.; Frydman, H. and Frydman, R. 2001. Cost inefficiency, size of firms, and takeovers. Review of Quantitative Finance and Accounting 17:397-420.

Wheelock, D. C. and Wilson, P. W. 2000. Why do banks disappear? The determinants of U.S. bank failures and acquisitions. Review of Economics and Statistics February: 127-138. 